\title{
PROFIL KOMPETENSI SISWA SMK KOMPETENSI KEAHLIAN TEKNIK KENDARAAN RINGAN DI KOTA PEKALONGAN
}

\author{
Alan Andika Priyatama \\ Program Studi Pendidikan Teknologi dan Kejuruan PPs UNY \\ alanandika03@yahoo.com, \\ Sukardi \\ Fakultas Teknik Universitas Negeri Yogyakarta \\ sukardimesin@yahoo.co.id
}

\begin{abstract}
Abstrak
Tujuan penelitian ini adalah untuk: (1) memperoleh informasi tentang profil kompetensi siswa serta ketersediaan fasilitas belajar; (2) untuk mengetahui nilai kompetensi siswa dengan standar kualifikasi kompetensi yang dibutuhkan di dunia kerja; (3) untuk menganalisis pengaruh kurikulum, kinerja mengajar guru, dan praktik kerja industri terhadap kompetensi siswa SMK Kompetensi Keahlian Teknik Kendaraan Ringan di Kota Pekalongan. Jumlah anggota populasi pada penelitian ini adalah 305 siswa, dengan sampel 237 siswa yang diambil menggunakan teknik Klaster. Penelitian ini merupakan penelitian ex-post facto dengan pendekatan kuantitatif. Selanjutnya teknik pengumpulan data adalah dengan cara penyebaran angket yang menggunakan model skala rating, yang dianalisisa dengan analisis regresi ganda. Hasil penelitian menunjukan bahwa: (1) profil kompetensi siswa SMK Kompetensi Keahlian Teknik Kendaraan Ringan di Kota Pekalongan telah sesuai dengan kebutuhan SKKNI Teknik Kendaraan Ringan dengan kontribusi kurikulum sebesar 17,06\%, kinerja guru 37,49\% dan prakerin 21,08\% serta ketersediaan fasilitas belajar sudah memadai; (2) Kompetensi siswa SMK Kompetensi Keahlian Teknik Kendaraan Ringan di Kota Pekalongan secara rata-rata adalah baik dan relevan dengan kebutuhan dunia kerja dengan nilai rata-rata sebesar 83.77; (3) kurikulum, kinerja guru dan praktik kerja industri berpengaruh positif dan signifikan terhadap kompetensi siswa SMK Kompetensi Keahlian Teknik Kendaraan Ringan di Kota Pekalongan.
\end{abstract}

Kata kunci: kompetensi siswa SMK, kurikulum, kinerja guru, praktik kerja industri.

\section{COMPETENCY PROFILE OF THE STUDENT OF SMK SKILL COMPETENCEOF LIGHT VEHICLE ENGINEERING IN PEKALONGAN}

\begin{abstract}
The aims of this research were: (1) to obtain information about Students competency profiles and the availability of learning facilities; (2) to determine the students competency level using the standard qualifications needed for future job; (3) to analyze the effect of the curriculum, teacher proficiency and industry job practices on competencies of the students of SMK Skill Competence of Light Vehicle Engineering in Pekalongan.The number of the population in this study about 305 students, with sample number of 237 respondens had drawn using claster sampling techniques. This research was ex-post facto with the quantitative approach. Futhermore, the techniques of data collection are by way of distributing a questionnare using rate scale models, which were analysed by multiple regression.The results of the research show that: (1) the competency profile of the students of SMK Skill Competence of Light Vehicle Engineering students in Pekalongan in accordance with the requirements SKKNI Light Vehicle Engineering with 17.06\% contribution of the curriculum, $37.49 \%$ contribution of teacher performance and $21.08 \%$ contribution of industry job practices and availability of learning facilities is adequate. (2) the competencies of the students of SMK Skill Competence of Light Vehicle Engineering in Pekalongan in average is good and relevant to the needs of the workforce with an average value of $83.77 ;$; (3) the curriculum, teachers proficiency and industry job practice have a positive and significant effect on the competencies of the students of SMK Skill Competence of Light Vehicle Engineering in Pekalongan.
\end{abstract}

Keywords: competencies of SMK students, curriculum, teacher proficiency, industry job practices 


\section{PENDAHULUAN}

Sekolah Menengah Kejuruan (SMK) merupakan bagian dari sektor ekonomi yang mendorong pertumbuhan ekonomi nasional sehingga perlu untuk dikembangkan kualitas dan kuantitasnya. Kualitas SMK akan merefleksikan kualitas tenaga kerja Indonesia yang perlu terus dibangun untuk meningkatkan keungulan kompetitif SDM. SMK sebagai lembaga pendidikan kejuruan merupakan motor penggerak ekonomi dan sosial di masyarakat. SMK diharapkan mampu menciptakan efek ganda yaitu mendorong capaian pendidikan warga sekaligus juga berkontribusi langsung terhadap pertumbuhan ekonomi.

The United Congress (Calhoun, 1976:

2) mendefinisikan pendidikan kejuruan:

Vocational education as organized educational programs which are directly related to the preparation of individuals for paid or unpaid employement, or for additional preparation for a career requiry other than a baccalaureate of advanced degree.

Definisi di atas, memberikan pengertian bahwa pendidikan kejuruan adalah suatu program pendidikan yang menyiapkan individu peserta didik menjadi tenaga kerja yang profesional, juga siap untuk dapat melanjutkan pendidikan ke jenjang yang lebih tinggi. Besarnya harapan tersebut terletak pada output yang dihasilkan dimana lulusan dapat langsung berpartisipasi aktif dalam bidang kerja. Pendidikan kejuruan memiliki multifungsi yang apabila dilaksanakan dengan baik akan berkontribusi besar terhadap pencapaian tujuan nasional. Peningkatan kuantitas dan perbaikan kualitas Sekolah Menengah Kejuruan merupakan syarat yang diperlukan bagi tersedianya angkatan kerja yang diharapkan mampu memainkan peran sebagai aset pembangunan bukan sebaliknya malah menjadi beban. Kondisi Indonesia memiliki kecenderungan yaitu, para pelaku dunia industri lebih tertarik dan berminat dengan lulusan SMK dalam menggerakkan semua aspek roda industri. Itu sebabnya di masa mendatang kebutuhan tenaga kerja masih tertumpu dari lulusan SMK untuk ikut memajukan pembangunan industri. SMK sebagai lembaga pendidikan yang mengutamakan keunggulan SDM harus berorientasi pada dunia industri, dunia industri yang merupakan sasaran dari proses dan hasil pembelajaran, oleh karena itu SMK harus memiliki pendekatan pembelajaran yang sesuai dengan dunia kerja.

Kota Pekalongan sudah dikategorikan sebagai kota jasa, perdagangan dan industri. Hal ini mengindikasikan bahwa aktivitas perekonomian dan penyerapan tenaga kerja didominasi ketiga sector tersebut. Berdasarkan hasil wawancara Kanit Regiden Satlantas Polres Pekalongan Kota dengan Radio Kota Batik (24 Desember 2011) mengatakan jumlah pengguna kendaraan di Kota Pekalongan mencapai sekitar 128 ribu kendaraan dari berbagai jenis Keadaan ini membuka peluang kerja di bidang Otomotif, khususnya sebagai teknisi mekanik, pelayan suku cadang dan operator di berbagai perusahaan dan bengkel serta memberi peluang bagi lulusan SMK Teknik Kendaraan Ringan untuk berwirausaha dengan membuka bengkel sendiri.

Peluang untuk bekerja pada bidang kompetensi keahlian teknik kendaraan ringan sangat besar, oleh sebab itu dibutuhkan tenaga kerja yang profesional. Kompetensi keahlian siswa sering dipertanyakan dan diangggap belum cukup untuk memenangkan persaingan tersebut. Padahal selama mengikuti proses belajar mengajar sekolah telah menyusun program pendidikan (kurikulum), siswanya telah diajar oleh tenaga pendidik yang kompeten, telah mengikuti praktik kerja industri selama 2-6 bulan di dunia kerja dan dilengkapi fasilitas belajar yang berpengaruh besar sebagai komponen pembentukan profil kompetensi siswa yang mencakup atas pengetahuan, ketrampilan dan sikap dalam menyelesaikan suatu pekerjaan atau tugas tertentu.

\section{Fasilitas Belajar}

Suharsimi Arikunto (1987: 6) berpendapat bahwa fasilitas adalah segala sesuatu yang dapat memudahkan dan melancarkan pelaksanaan suatu usaha. Selanjutnya The Liang Gie (2002: 46) menyatakan bahwa fasilitas adalah persyaratan yang meliputi keadaan sekeliling tempat belajar dan keadaan jasmani siswa atau anak.

Terdapat beberapa keuntungan bagi sekolah yang memiliki kelengkapan sarana dan prasarana, diantaranya dapat merangsang siswa untuk belajar dan menumbuhkan gairah daan motivasi guru untuk mengajar. Dalam hubungan ini Hoy dan Miscel (1987: 32) mengemukakan "Scholl are service organiza- 
tions that the are committed to teaching and learning".

Bahwa sekolah adalah organisasi (jasa/ layanan) yang merasa terikat atau memiliki komitmen dengan pengajaran dan belajar. Hampir secara mutlak dapat dikatakan bahwa sarana dan prasarana baik itu berupa bahan atau alat dapat menyalurkan pesan secara efektif dan efisien yang mendorong siswa untuk menentukan pilihan siswa dalam belajar. Uline (2006: 56) menyatakan "School climate may explain, at least in part, the deleterious impact that poor school facilities has on learning".

Secara bebas berarti bahwa iklim pembelajaran di sekolah adalah menjelaskan, dalam proses menjelaskan tersebut tentunya sekolah dengan minim fasilitas akan memberikan dampak pada proses pembelajaran. Kelengkapan fasilitas belajar yang termasuk di dalamnya sarana dan prasarana secara tidak langsung mendukung keberhasilan proses pembelajaran, kelengkapan fasilitas belajar akan membantu guru dalam menyelenggarakan proses pembelajaran dan fasilitas belajar merupakan komponen penting dalam mempengaruhi proses pembelajaran. Pemerintah Indonesia memperhatikan keberadaan fasilitas belajar di dunia pendidikan seperti yang tercantum di dalam UU No. 20 Tahun 2003 tentang SISDIKNAS pasal 45 ayat 1 sebagai berikut:

Setiap satuan pendidikan formal dan non formal menyediakan sarana dan prasarana yang memenuhi keperluan pendidikan sesuai dengan pertumbuhan dan perkembangan potensi fisik, kecerdasan intelektual, sosial emosional, dan kajiwaan peserta didik.

Kelengkapan fasilitas belajar yang didalamnya termasuk sarana dan prasarana tentunya merupakan hal yang mutlak dan komponen utama dalam proses pembelajaran di Sekolah kejuaruan yang menekankan pada keadaan dan kondisi nyata di dunia kerja, dan kondisi yang ideal adalah bahwa kondisi di Sekolah Kejuruan merupakan replika di dunia nyata dengan fasilitas belajar yang tidak terlalu jauh rentang perbedaannya dengan di dunia usaha maupun di dunia industri. Ketersediaan fasilitas belajar yang lengkap memungkinkan guru memiliki berbagai pilihan yang dapat digunakan untuk melaksanakan fungsi mengajarnya dan dapat memberikan pilihan bagi siswa untuk belajar.

\section{Kurikulum}

Kurikulum berkembang sejalan dengan perkembangan teori dan praktik pendidikan, kurukulum juga merupakan salah satu alat untuk mencapai tujuan pendidikan dan sebagai pedoman dalam pelaksanaan pembelajaran pada sekolah. Seluruh perangkat dalam kurikulum berperan sebagai suatu program pendidikan yang dapat memberikan kontribusi terhadap proses dan hasil pendidikan.

Zais (1976: 6) mengemukakan bahwa kurikulum adalah "the curriculum is a resources of subject matters to be mastered". Artinya bahwa kurikulum haruslah mencakup pokok-pokok mata pelajaran yang harus dikuasai. Sedangkan menurut Tyler (1949: 20) kurikulum diartikan sebagai pengalaman belajar yang direncanakan dan diarahkan oleh lembaga untuk mencapai tujuan pendidikan. Olson (2010:169) menyatakan "The paradigmatic nature of curriculum as a course of study is woven into and transforms individuals' narratives of experience". Paradigma alami dari kurikulum suatu bidang studi adalah merajut serta mengubah pengalaman peserta didik dalam suatu rangkaian waktu.

Relevansi materi, Proses pembelajaran, Kemitraan dengan DU/DI, dan Program pengembangan diri merupakan Implementasi kurikulum pada SMK yang identik dengan perubahan. Ornstein (1988: 305) menjelaskan bahwa perubahan diakibatkan oleh pengetahuan baru, bagaimanapun dengan hadirnya pengetahuan baru, akan menimbulkan perubahan. Semua orang harus mengenal perubahan untuk persiapan akan adanya perubahan cepat ataupun lambat. Mengutip Bashinski (2002) menyatakan bahwa:

Adapting the curriculum involves differentiating instruction to provide learners with a variety of ways to process information and demonstrate what they have learned, in order to "match" the way in which each learner learns most effectively.

Mengimplementasikan kurikulum berarti memfasilitasi peserta didik dalam memperoleh informasi dan medemostrasikan atas apa yang mereka pelajari dan menyelaraskannya dengan kondisi yang nyata. Kuri- 
kulum tidak hanya menunjukan adanya perubahan penekanan dari isi kepada proses, tetapi menunjukan adanya perubahan lingkup, yaitu dari konsep yang sangat sempit ke konsep yang lebih luas.

Implikasi dari struktur kurikulum tersebut adalah guru-guru akan berinteraksi secara harmonis tentang bahan yang akan diajarkan, guru produktif akan menyampaikan sejumlah target pencapaian kompetensi, kemudian direspon oleh guru-guru normatif dan adaptif, untuk memberikan penyesuaian yang saling memperkuat dalam pencapaian ketuntasan kompetensi.

Berdasarkan struktur kurikulum dan implikasinya, maka struktur kurikulum SMK untuk Kompetensi Keahlian Teknik Kendaraan Ringan. Mata pelajaran kejuruan terdiri atas beberapa mata pelajaran yang dikelompokkan dalam Dasar Kompetensi Kejuruan dan Kompetensi Kejuruan, dikembangkan mengacu pada Standar Kompetensi Kerja melalui proses analisis. Jika standar kompetensi mata pelajaran kelompok Dasar Kompetensi Kejuruan tidak dijumpai pada Standar Kompetensi Kerja, maka Standar Kompetensi dan Kompetensi Dasar dapat dirumuskan melalui analisis kompetensi kejuruan.

\section{Kinerja Guru}

Guru merupakan komponen penting dan memiliki posisi sentral dalam proses pembelajaran, guru sebagai pendidik adalah tokoh yang paling banyak bergaul dan berinteraksi dengan para murid dibandingkan dengan personel lainnya di sekolah. Guru bertugas merencanakan dan melaksanakan proses pembelajaran, menilai hasil pembelajaran, melakukan bimbingan dan pelatihan, melakukan penelitian dan pengkajian, dan membuka komunikasi dengan masyarakat. Kompetensi pedagogik dan kompetensi profesional mengambil peranan kunci yang sangat penting dalam mempersiapkan guru dalam pembelajaran yang mempunyai tanggung jawab dan beban yang tidak ringan dalam menjawab tantangan sebagai seorang pelatih, pembimbing dan manager belajar dalam pembelajaran bagi peserta didiknya.

Guru sebagai pendidik ataupun pengajar merupakan faktor penentu kesuksesan setiap usaha pendidikan. Selanjutnya Hammond (2012) menyatakan bahwa:
Individual teacher evaluation is based on the belief that measured achievement gains for a specific teacher's students reflect that teacher's "effectiveness." This attribution, however, assumes that student learning is measured well by a given test, is influenced by the teacher alone, and is independent from the growth of classmates and other aspects of the classroom context.

Pencapaian kinerja guru dapat diukur atau dapat direfleksikan dari siswa yang memperoleh pengajaran dari guru tersebut, apabila hasil belajar siswa diukur dengan diberikan test tentunya hasil siswa tersebut di merupakan hasil kinerja guru itu sendiri dan juga kemandirian yang muncul pada teman sekelas serta aspek lain dalam kontek pembelajaran di kelas. Wujud perilaku dalam kinerja guru yaitu kegiatan guru dalam kegiatan belajar mengajar yang dimaksudkan pada pencapaian tujuan pendidikan yang ingin dicapai yaitu output siswa yang optimal baik secara kualitas dan kuantitas. Berdasarkan analisis teori dapat ditarik sebuah kesimpulan bahwa yang dimaksud penilaian kinerja guru adalah dengan unjuk kerja guru dalam menjalankan tugasnya dalam upaya mencapai tujuan pendikan dan pengajaran yang mencakup: merencanakan pembelajaran, melaksanakan pembelajaran dan yang terakhir adalah melakukan evaluasi pembelajaran.

\section{Praktik Kerja Industri}

Praktik kerja industri merupakan suatu kewajiban bagi siswa SMK yang merupakan bagian dari proses pendidikan dan pelatihan di SMK. Praktik kerja industri merupakan suatu langkah nyata hubungan kerjasama dengan dunia kerja untuk membuat sistem pendidikan dan pelatihan kejuruan lebih relevan dengan dunia kerja dalam rangka menghasilkan tamatan yang bermutu. Jeongwoo Lee (2010: 54) menyatakan:

Strengthened partnerships will help alleviate poverty by reducing labor and skill mismatch by making labor pooling and matching available. Increased skills formation will allow trainees to engage themselves in income generating opportunities, which may include both employment by the industry and self-employment. 
Penguatan kemitraan akan membantu dalam mengurangi kesenjangan dan ketidak cocokan kemampuan dan ketrampilan tenaga kerja yang tersedia dengan membuat penyatuan dan pencocokan dengan ketrampilan yang sesuai dengan kebutuhan dunia kerja. Dengan peningkatan ketrampilan akan memungkinkan peserta didik untuk mendapatkan kesempatan lebih luas dalam berkarir di dunia kerja ataupun berwirausaha.

Tujuan prakerin salah satunya adalah untuk memberikan pengalaman serta mempraktikan ilmu dan ketrampilan yang sudah dia peroleh di sekolah dengan kondisi nyata di dunia kerja. Oemar Hamalik (1990: 205) mengemukakan bahwa tujuan praktik kerja industri adalah memberi kesempatan kepada peserta didik sekolah kejuruan untuk mendalami dan menghayati situasi dan kondisi dunia usaha yang aktual sesuai dengan program studi yang sedang didalaminya.

Penilaian dan sertifikasi pelaksanaan praktik kerja industri diuji dan dinilai oleh pihak sekolah dan dunia kerja sebagai institusi pasangan. Evaluasi dari pelaksanaan praktik kerja industri mencakup peningkatan pengetahuan, sikap, ketrampilan dan wawasan yang diperoleh melalui kegiatan pembelajaran di dunia kerja. Siswa yang telah melaksanakan praktik kerja industri akan mendapatkan penghargaan berupa sertifikat (surat keterangan) prakerin yang menjelaskan kemampuan atau kompetensi yang dimiliki oleh siswa sesuai dengan tingkat kemampuan yang telah dilaksanakan dengan memperhatikan hasil atau nilai yang diperoleh oleh siswa selama mengikuti program praktik kerja industri. Hasil evaluasi mempunyai dampak yang dapat mempengaruhi tindak lanjut setelah praktik kerja industri. Hasil praktik kerja industri dapat menjadi bekal peserta diklat untuk memasuki dunia kerja sesungguhnya setelah peserta didik lulus dari SMK.

\section{Kompetensi Siswa}

Gambaran tentang kualitas lulusan pendidikan kejuruan yang disarikan oleh Finch dan Crunkilton (1999: 15-16), yaitu kualitas pendidikan kejuruan menerapkan ukuran ganda, yaitu berkualitas di sekolah atau inschool success standards dan berkualitas di masyarakat out-of school success standarts. Kriteria pertama meliputi aspek keberhasilan peserta didik dalam memenuhi tuntutan kuri- kuler yang diorentasikan pada tuntutan dunia kerja, sedangkan kriteria kedua, meliputi keberhasilan peserta didik yang diperlihatkan pada kemampuan unjuk kerja sesuai dengan standar kompetensi nasional ataupun internasional setelah mereka berada di lapangan kerja yang sebenarnya.

Profil kompetensi lulusan SMK terdiri atas kompetensi umum dan kompetensi kejuruan, yang masing-masing telah memuat kompetensi kunci. Kompetensi umum mengacu pada tujuan pendidikan nasional dan kecakapan hidup generik, sedangkan kompetensi kejuruan mengaju pada Standar Kompetensi Kerja Nasional Indonesia (SKKNI).

\section{METODE}

Jenis penelitian dalam penelitian ini adalah penelitian ex-post facto dengan pendekatan yang dilakukan adalah pendekatan kuantitatif. Tempat penelitian ini dilakukan di SMK di Kota Pekalongan, yakni SMK Muhammadiyah Pekalongan, SMK Dwija Praja Pekalongan dan SMK Syafi'i Akrom Pekalongan, Data mengenai ketiga SMK di sajikan pada berikut ini. Penelitian ini dilakukan dengan menyesuaikan jadwal pada bulan oktober sampai dengan juni untuk siswa kelas XII SMK tahun ajaran 2012/2013 di Kota Pekalongan. Populasi penelitian adalah seluruh siswa tingkat III (kelas XII) pada 3 sekolah SMK Kompetensi Keahlian Teknik Kendaraan Ringan di Kota Pekalongan. Dari total populasi sebanyak 302 siswa, diperoleh sampel sebanyak 237 sampel melalui teknik klaster dan untuk menentukan sampel dalam penelitian ini dilakukan dengan menggunakan formula empiris dianjurkan oleh (Isaac \& Michael dalam Sukardi, 2011: 55). Instrumen pengumpulan data yang digunakan dalam penelitian ini adalah dengan metode berikut: 1) data dari pengamatan; 2) data dari dokumentasi; 3) data dari pencermatan; dan 4)angket menggunakan skala rating dengan alternatif empat jawaban. Angket penelitian sebelum digunakan divalidasi ahli dan diujicobakan pada 34 siswa untuk menguji validitas dan realiabilitas instrument. Teknik analisis data dengan menggunakan analisis deskriptif dan infrensial (regresi ganda) menggunakan program SPSS for windows 14, yang sebelumnya data 
telah melalui uji prasyarat analisis antara lain: uji normal, linier, multikolinier dan heterokedasitas.

\section{HASIL PENELITIAN DAN PEMBAHASAN}

Berdasarkan hasil dari observasi semua aspek yang menjadi penilaian dalam ketersediaan fasilitas belajar yang diadaptasi dari Standar Fasilitas untuk SMK Teknik Kendaraan Ringan Permendiknas RI Nomor 40 tahun 2008 yang di dalamnya terdapat dimensi ruang pembelajaran umum, area kerja (bengkel), area kerja kelistrikan, area kerja chasis dan pemindah daya serta ruang penyimpanan instruktur. Berikut hasil dari observasi ketersediaan fasilitas belajar.

Tabel 1. Hasil Observasi

\begin{tabular}{ccc}
\hline Lokasi Kajian & Persentase & Kualifikasi \\
\hline $\begin{array}{c}\text { SMK } \\
\text { Muhamadiyah } \\
\text { SMK Dwija } \\
\text { Praja }\end{array}$ & $81 \%$ & $\begin{array}{c}\text { Sangat } \\
\text { memadai }\end{array}$ \\
$\begin{array}{c}\text { SMK Syafi'I } \\
\text { Akrom }\end{array}$ & $63 \%$ & Memadai \\
\hline Mean & & Memadai \\
\hline
\end{tabular}

Selanjutnya berdasarkan hasil observasi yang diakukan maka diperoleh gambaran SMK Teknik Kendaraan Ringan di kota Pekalongan disajikan pada Tabel 2.

Tabel 2. Profil SMK Teknik Kendaraan Ringan di Kota Pekalongan

\begin{tabular}{lccc}
\hline Lokasi Kajian & $\begin{array}{c}\text { SMK } \\
\text { Muham- } \\
\text { madiyah }\end{array}$ & $\begin{array}{c}\text { SMK } \\
\text { Dwija Praja }\end{array}$ & $\begin{array}{c}\text { SMK } \\
\text { Syafi'I } \\
\text { Akrom }\end{array}$ \\
\hline Guru Produktif & & & \\
\hline \multicolumn{1}{c}{ S1/D IV } & 9 & 7 & 3 \\
$\quad$ Dip & & 1 & 1 \\
\hline Jumlah siswa & & & \\
\hline \multicolumn{1}{c}{ Tingkat I } & 144 & 128 & 88 \\
$\quad$ Tingkat II & 109 & 148 & 73 \\
$\quad$ Tingkat III & 86 & 140 & 76 \\
\hline $\begin{array}{l}\text { Lamanya } \\
\text { mengikuti }\end{array}$ & 2 bulan & 2 Bulan & 2 Bulan \\
Prakerin & & & \\
\hline
\end{tabular}

Berdasarkan tabel diatas terlihat bahwa jumlah tenaga pendidik (guru produktif) Teknik Kendaraan Ringan pada masing-masing SMK dapat dikatakan mencukupi untuk mendidik dan melatih siswa SMK untuk kompetensi keahlian Teknik Kendaraan Ringan.

Ketersediaan fasilitas belajar secara keseluruhan dapat dikatakan memadai dan lamanya siswa SMK kompetensi keahlian Teknik Kendaraan Ringan mengikuti prakerin adalah selama 2 bulan. Selanjutnya Hasil pengujian melalui bantuan program SPSS 14 for window maka diperoleh deskripsi/gambaran statistik tentang variabel kurikulum sebagai variabel bebas $\left(X_{1}\right)$ dengan penjelasan disajikan pada Tabel 3.

Tabel 3. Statistics Variabel Kurikulum

\begin{tabular}{lrr}
\multicolumn{2}{c}{ Statistics } \\
\hline Kurikulum & & \\
\hline $\mathrm{N}$ & Valid & 237 \\
& Missing & 0 \\
Mean & & 63,81 \\
Median & 64,00 \\
Mode & 65 \\
Std. Deviation & & 6,126 \\
Variance & 37,527 \\
Skewness &,- 209 \\
Std. Error of Skewness &, 158 \\
Kurtosis &, 183 \\
Std. Error of Kurtosis & & 315 \\
Range & 37 \\
Minimum & 43 \\
Maximum & 80 \\
Sum & & 15123 \\
Percentiles & & 60,00 \\
& 25 & 64,00 \\
& & 68,00 \\
\hline \multicolumn{2}{c}{} &
\end{tabular}

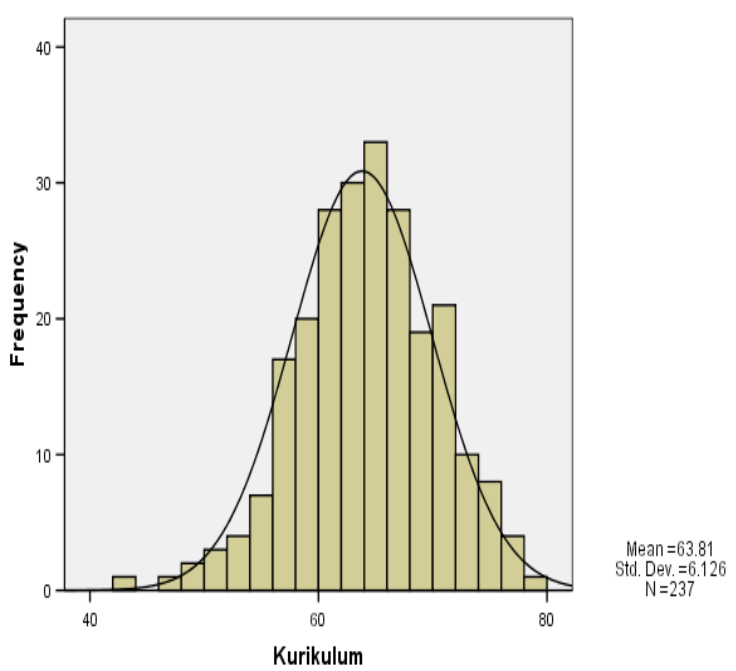

Gambar 1. Histogram Variabel Kurikulum 
Berdasarkan hasil pengujian melalui bantuan program SPSS 14 di atas, ubahan variabel kurikulum nilai skewness nya sebesar $-0,209$ atau juling (-) dengan posisi mean < median < mode. Ini berarti ubahan variabel kurikulum sudah baik dan tinggal mempertahankan atau meningkatkan sehingga program pendidikan atau kurikulum dari SMK Kompetensi keahlian Teknik Kendaraan Ringan di Kota Pekalongan mampu mengakomodasi serta menyiapkan sumber daya manusia yang berkualitas sesuai dengan tuntutan pasar kerja atau kebutuhan dunia kerja. Hasil pengujian melalui program SPSS 14 for window maka diperoleh deskripsi/gambaran statistik tentang variabel kinerja guru sebagai variabel bebas $\left(X_{2}\right)$ dengan penjelasan tercantum pada Tabel dibawah ini:

Tabel 4. Statistics Variabel Kinerja guru

\begin{tabular}{lcr}
\multicolumn{2}{c}{ Statistics } \\
\hline Kinerja Guru & & \\
\hline $\mathrm{N}$ & Valid & 237 \\
& Missing & 0 \\
Mean & & 80,79 \\
Median & & 81,00 \\
Mode & 84 \\
Std. Deviation & 9,693 \\
Variance & 93,955 \\
Skewness & & -291 \\
Std. Error of Skewness & & 158 \\
Kurtosis & & 252 \\
Std. Error of Kurtosis & &, 315 \\
Range & & 60 \\
Minimum & & 44 \\
Maximum & & 104 \\
Sum & & 19147 \\
Percentiles & 10 & 68,00 \\
& 25 & 73,00 \\
& 50 & 81,00 \\
& & 87,00 \\
\hline \multicolumn{2}{c}{ Histogram } \\
\end{tabular}

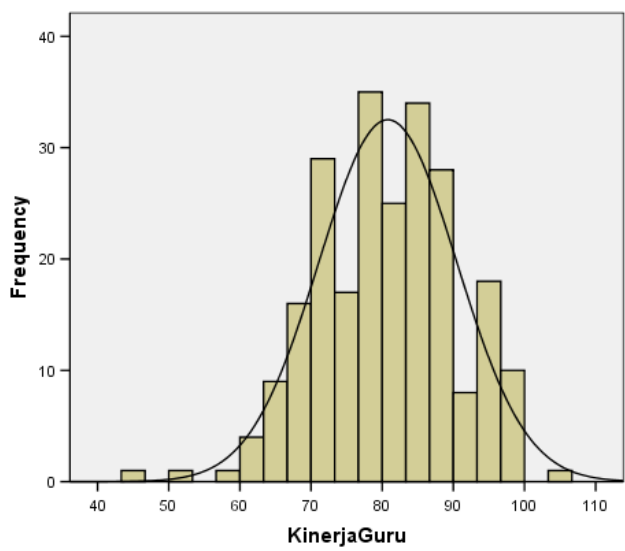

$\begin{aligned} \text { Mean } & =80.79 \\ \text { Std. } D e v . & =9.693 \\ N & =237\end{aligned}$

Gambar 2. Histogram Variabel Kinerja guru
Berdasarkan hasil pengujian melalui bantuan program SPSS 14 di atas, ubahan variabel kinerja guru nilai skewness nya sebesar -0,291 atau juling (-) dengan posisi mean < median < mode, maka dapat disimpulkan bahwa bahwa kinerja mengajar guru pada SMK Kompetensi keahlian Teknik Kendaraan Ringan di Kota Pekalongan sudah baik dan sudah berada di atas rerata.

Hasil pengujian melalui program SPSS 14 for window maka diperoleh deskripsi/ gambaran statistik tentang variabel Prakerin sebagai variabel bebas $\left(\mathrm{X}_{3}\right)$ dengan penjelasan disajikan pada Tabel 5 .

Tabel 5. Statistics Variabel Prakerin

\begin{tabular}{lrr}
\multicolumn{2}{c}{ Statistics } \\
\hline Prakerin & Valid & 237 \\
& Missing & 0 \\
Mean & & 78,70 \\
Median & & 79,00 \\
Mode & 80 \\
Std. Deviation & & 7,605 \\
Variance & & 57,855 \\
Skewness & &,- 027 \\
Std. Error of Skewness & &, 158 \\
Kurtosis &,- 204 \\
Std. Error of Kurtosis & &, 315 \\
Range & & 38 \\
Minimum & & 60 \\
Maximum & & 98 \\
Sum & & 18652 \\
Percentiles & & 73,00 \\
& 20 & 79,00 \\
& 50 & 84,00 \\
\hline
\end{tabular}

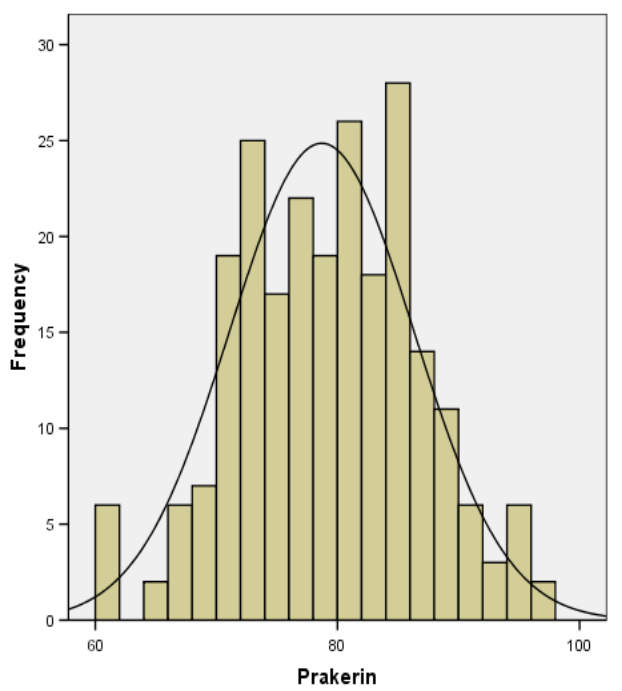

$\begin{aligned} & \text { Mean }=78.7 \\ & \text { Std. Dev }=7.606 \\ & N=237\end{aligned}$

Gambar 3. Histogram Variabel prakerin 
Dari hasil analisis diketahui nilai skewness nya sebesar $-0,027$ adalah negatif, jadi kurva condong negatif atau posisi mean < median < mode. Ini berarti ubahan variabel nilai prakerin sudah baik dan tinggal mempertahankan atau meningkatkan menjadi lebih baik di masa yang akan datang. Hasil pengujian melalui program SPSS 14 for window maka diperoleh deskripsi/gambaran statistik tentang variabel kompetensi siswa sebagai variabel terikat $(\mathrm{Y})$ dengan penjelasan tercantum pada Tabel6.

Tabel 6. Statistics Variabel Kompetensi Siswa

\begin{tabular}{lrr}
\multicolumn{2}{c}{ Statistics } \\
\hline Prakerin & & \\
\hline $\mathrm{N}$ & Valid & 237 \\
& Missing & 0 \\
Mean & & 83,77 \\
Median & & 84,00 \\
Mode & 85 \\
Std. Deviation & 6,081 \\
Variance & 36,973 \\
Skewness &,- 249 \\
Std. Error of Skewness & &, 158 \\
Kurtosis & 105 \\
Std. Error of Kurtosis & &, 315 \\
Range & & 34 \\
Minimum & & 63 \\
Maximum & & 97 \\
Sum & & 19854 \\
Percentiles & 20 & 80,00 \\
& 50 & 84,00 \\
& 75 & 88,00 \\
\hline
\end{tabular}

Dari hasil analisis nilai skewness nya sebesar -0,249 adalah negatif, jadi kurva condong negatif (ke kanan) menunjukkan kedekatan dengan nilai 0 dengan posisi mean < median < mode. Ini berarti bahwa nila kompetensi siswa sudah baik dan sudah berada di atas rerata.Selanjutnya berdasarkan data hasil analisis diatas dapat diketahui bahwa nilai rata-rata siswa SMK Kompetensi keahlian Teknik Kendaraan Ringan di Kota Pekalongan adalah 83,77, hal ini menunjukan kompetensi yang dimiliki siswa secara ratarata adalah baik dan relevan dengan kebutuhan dunia kerja

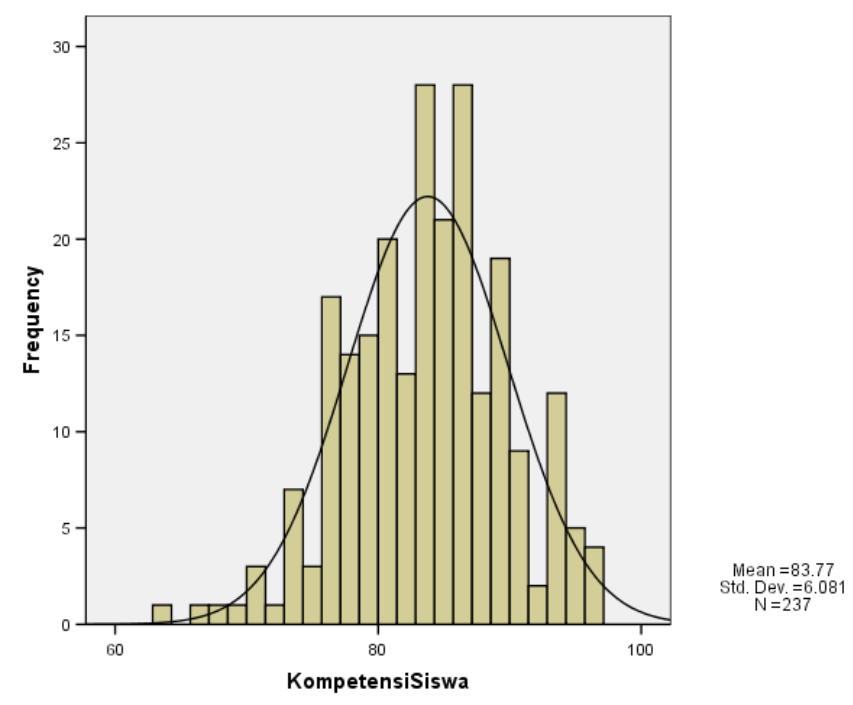

Gambar 4. Histogram Variabel Kompetensi siswa

Untuk memprediksi kompetensi siswa SMK, selanjutnya tiga variabel yang dianggap memberikan pengaruh terhadap kompetensi siswa SMK secara serentak dimasukkan ke dalam fungsi persamaan regresi berganda. Hasil pengujian melalui program SPSS 14 for window maka diperoleh hasil statistik sebagai berikut:

Tabel 7. Hasil Uji Coba Regresi Ganda

\begin{tabular}{llrrrrr}
\hline \multirow{2}{*}{ Model } & \multicolumn{2}{c}{$\begin{array}{c}\text { Unstandardized } \\
\text { Coefficients }\end{array}$} & \multicolumn{2}{c}{$\begin{array}{c}\text { Standardized } \\
\text { Coefficients }\end{array}$} & \multirow{2}{*}{ Sig. } \\
\cline { 2 - 4 } & \multicolumn{1}{c}{ B } & Std. Error & Beta & & \\
\hline 1 & (Constant) & 18,881 & 2,609 & & 7,236 &, 000 \\
& Kurikulum &, 275 &, 037 &, 277 & 7,339 &, 000 \\
& Kinerja Guru &, 310 &, 024 &, 494 & 12,674 &, 000 \\
& Prakerin &, 283 &, 028 &, 355 & 10,240 &, 000 \\
\hline
\end{tabular}

a. Depent variable: Kompetensi Siswa 
Berdasarkan tabel di atas maka hubungan fungsional antara variabel terikat $(\mathrm{Y})$ dengan variabel bebas $\left(X_{1}, X_{2}, X_{3}\right)$ dapat digambarkan dari hasil perhitungan regresi ganda dalam bentuk persamaan regresi berganda sebagai berikut:

$\hat{\mathrm{Y}}=18,881+0,275 X_{1}+0,310 X_{2}+0,283 X_{3}+\varepsilon$

Berdasarkan persamaan tersebut, dapat diterangkan bahwa:

1. Jika setiap kali ubahan variabel kurikulum bertambah satu, maka rerata nilai kompetensi siswa akan bertambah sebesar 0,275.

2. Jika setiap kali ubahan variabel kinerja mengajar guru bertambah satu, maka re- rata nilai kompetensi siswa akan bertambah sebesar 0, 310 .

3. Jika setiap kali ubahan variabel kinerja mengajar guru bertambah satu, maka rerata nilai kompetensi siswa akan bertambah sebesar 0, 283.

Berdasarkan hasil analisis di atas dapat dihitung kontribusi masing-masing variabel bebas terhadap kompetensi siswa SMK Kompetensi Keahlian Teknik Kendaraan Ringan di Kota Pekalongan. Adapun kontribusi setiap ubahan variabel disajikan pada tabel di bawah ini:

Tabel 8. Kontribusi Variabel X terhadap Y

\begin{tabular}{llcclc}
\hline No & variabel & $\mathrm{R}$ & $\mathrm{B}$ & Perhitungan & Kontribusi \\
\hline 1 & $X_{2}$ (Kinerja guru) & 0,759 & 0,494 & $0,759 \times 0,494 \times 100$ & $37,49 \%$ \\
2 & $X_{3}$ (Prakerin) & 0,594 & 0,355 & $0,594 \times 0,355 \times 100$ & $21,08 \%$ \\
3 & $X_{3}$ (Kurikulm) & 0,616 & 0,277 & $0,616 \times 0,277 \times 100$ & $17,06 \%$ \\
\hline \multicolumn{5}{c}{ Total } & $75,63 \%$ \\
\hline
\end{tabular}

Dari tabel diatas, menunjukan bahwa ubahan variabel kinerja guru $\left(\mathrm{X}_{2}\right)$ menunjukan kontribusi yang paling besar yaitu sebesar $37,49 \%$ selanjutnya dari hasil perhitungan tersebut diketahui bahwa prakerin $\left(\mathrm{X}_{3}\right)$ dan kurikulum $\left(\mathrm{X}_{1}\right)$ mampu memberikan kontribusi sebesar $21,08 \%$ dan $17,06 \%$ terhadap kompetensi siswa SMK Kompetensi Keahlian Teknik Kendaraan Ringan di Kota Pekalongan (Y). besarnya kontribusi total sama dengan besarnya koefisien determinasi ( $\mathrm{R}$ squre $=\mathrm{R} 2$ ) yaitu sebesar 75,6 \%. Implikasinya adalah terdapat beberapa variabel lain yang pengaruhnya mencapai $24,4 \%$ yang mempengaruhi kompetensi siswa selain kurikulum $\left(\mathrm{X}_{1}\right)$, kinerja guru $\left(\mathrm{X}_{2}\right)$ dan prakerin $\left(\mathrm{X}_{3}\right)$.

\section{SIMPULAN}

Berdasarkan hasil analisis dan pembahasan yang telah dilakukan dalam penelitian ini maka dapat disimpulkan beberapa hal sebagai berikut:

1. Profil Kompetensi siswa SMK Kompetensi Keahlian Teknik Kendaraan Ringan di Kota Pekalongan telah sesuai dengan kebutuhan SKKNI Teknik Kendaraan Ringan dengan kontribusi kurikulum sebesar $17,06 \%$, kinerja guru 37,49 \% dan prakerin $21,08 \%$ serta ketersediaan fasilitas belajar yang sudah memadai.

2. Kompetensi siswa SMK Kompetensi Keahlian Teknik Kendaraan Ringan di kota Pekalongan secara rata-rata adalah baik dan relevan dengan kebutuhan dunia kerja dengan nilai rata-rata sebesar 83,77.

3. Kurikulum, kinerja mengajar guru dan praktik kerja industri berpengaruh positif dan signifikan terhadap kompetensi siswa SMK Kompetensi Keahlian Teknik Kendaraan Ringan di kota Pekalongan.

\section{SARAN}

Berdasarkan hasil analisis dan kesimpulan diatas dapat dikemukakan saran sebagai berikut:

1. Kurikulum, kinerja guru dan prakerin serta kesediaan fasilitas belajar merupakan komponen penting dari pembentukan kompetensi siswa sehingga perlu ditingkatkan agar memberikan kontribusi yang besar terhadap kompetensi siswa. Antara lain dengan terus dilakukan peningkatan dan penyempurnaan kurikulum, Peningkatan kinerja guru dengan mengirim me- 
ngikuti pendidikan dan pelatihan, terus mengikuti dan melengkapi fasilitas belajar agar semakin sesuai dengan ketentuan permendiknas RI Nomor 40 Tahun 2008, serta menjalin kerja sama yang lebih baik dengan dunia kerja sebagai institusi pasangan dalam hal praktik kerja industri bagi para siswa Kompetensi Keahlian Teknik Kendaraan Ringan.

2. Penelitian ini hanya membahas beberapa komponen dalam pembentukan profil kompetensi siswa dengan kebutuhan dunia kerja, yaitu kurikulum, kinerja guru dan prakerin serta kesediaan fasilitas belajar, sedangkan secara obyektif masih banyak komponen lain dalam pembentukan profil kompetensi siswa. Maka agar komponen-komponen tersebut dapat diketahui besaran kontribusinya, perlu dilakukan penelitian lanjutan.

\section{DAFTAR PUSTAKA}

Bashinski, S.M. (2002). Adapting the curriculum to meet the needs of diverse learners. Diakses tanggal 19 November 2012, dari http://www.pbs.org/teachers/ earlychildhood/articles/adapting.html

Calhoun, C.C. \& Finch, A.V. (1976). Vocational education: concept and operations. Belmount, California: Wads Worth Publishing Company.

Finch, C. R \& Crunkilton, J. R. (1999). Curriculum development in vocational and technical education: planning, content and implementation. Boston: Allyn and Bacon, Inc.

Hammond, L.D. (2012). Evaluating teacher evaluation. Diakses tanggal 19 Novem- ber 2012 dari http://www.edweek.org/ ew/articles/2012/03/01/kappan hammo nd.html

Hoy \& Miscel. (1987). Education administration: Theory, Research and Practi$c e$. New York: Random Hause.

Lee, Jeongwoo. (2010). Partnerships with industry for efficient and effective implementation of TVET. International Journal of Vocational Education and Training. 2, 39-56.

Oemar Hamalik (1990). Metode belajar dan kesulitan-kesulitan belajar. Jakarta: Bina Angkasa.

Olson, Margaret. (2000). Curriculum as a multistoried process. Canadian Journal of Education, 25, 169-187.

Ormrod, Jeanne Ellis. (2003). Educational psychology developing learnenrs. Fourth edition. Boston: MA.

Suharsimi Arikunto. (1987). Pengelolaan materiil. Jakarta: Prima karya.

Sukardi.(2011). Metodologi penelitian pendidikan. Jakarta: Bumi Aksara.

The Liang Gie. (2002). Cara belajar yang efisisen. Yogyakarta: Liberty.

Tyler, R. W. (1949). Basic prinsiples of curriculum and instruction. Chicago. London: The University of Chicago Press.

Zais, R. (1976). Curriculum principles and foundations. New York: Harper \& Row Publishers. 